\title{
Spřažené edice: Leskov - práce o Gorkém
}

\author{
Ivo Pospíšil (Brno)
}

N. S. Leskov: Čortovy kukly. Izdanije podgotovila Alla A. Šelajeva. Sankt-Petěrburg: „Nauka“, 2015. 362 s. ISBN 978-5-02-038236-7.

Jaroslav Burian: Stanovlenije i razvitije žanra romana v tvorčestve Maksima Goŕkogo. Monografija. Perevod s češskogo A. S. Matvejevoj. Nižnij Novgorod: Izdatel'stvo Nižegorodskogo universiteta, 2017. 214 s. ISBN 978-5-91326-385-8.

Edice zpravidla nebývají pokládány za plnohodnotnou vědeckou práci, a to je nesprávné. Ve své nejkvalitnější podobě je to špičkový vědecký výkon, ale málokdy je slyšet, že by se za tyto edic udělovaly vědecké nebo vědeckopedagogické hodnosti, snad s výjimkou starších období starověku nebo středověku, případně raného novověku. Rusové mají k edicím blízko; ostatně samo „textologie“, jíž Poláci říkají „umění vydávat“ (sztuka edytorska) je v tomto významu ruského původu, byt je to, jak patrno, tradiční kompozitum greko-latinské; světově proslulý ruský medievista D. S. Lichačov je autorem její učebnice (jedna z novějších reedic je z roku 2006 a vyšla v nakladatelství Nauka, má víc než 700 stran; jeho první textologická črta je z roku 1962, potom měla různé materiálové varianty, „Ameriku objevil“ zpozdilý český překlad - až z roku 2015). Leskovův román Čertovská kvitka (Čortovy kukly, 1890) patří k jeho pozdnímu dílu a řadí se k jinému nedokončenému románu Přelet sokola (Sokolij perelët, 1883). Přelet sokola zůstal ve fragmentech; Leskov přestal totiž do časopisu, který román vydával, dodávat další text údajně z ideových důvodů. Pravou příčinou byla však spíše jeho úporná až křečovitá snaha vytvořit - po mnoha nezdarech - konečně dramatický román balzakovského typu - to se Leskovovi nikdy nepodařilo. Z jeho antinihilistických románů je mu nejbližší hned ten první, a to Neni kam jit (Nekuda, 1864) - podstatně méně úspěšné byly romány Oklamani (Obojdënnyje, 1865) a Na nože (Na nožach, 1871). Již v románu Nekuda se mu však text rozkládá na části v podstatě kronikového typu, jež potom rozvijí ve svých třech „historických kronikách“, zejména v románové kronice Soborjane (1872, Duchovenstvo sborového chrámu, čes. 1903, přel. A. G. Stin/A. A. Vrzal, jiný název Služebníci chrámu - autor Roman Mrázek), ještě dříve ve fragmentech kroniky Staré roky v Plodomasově (Staryje gody v sele Plodomasove, 1869) a Zchudlý rod (Zachudalyj rod, 1874, čes. jako Soumrak knížecího rodu, 1983, přel. Naděžda Slabihoudová). Přelet sokola a potom Čortovy kukly jsou posledním pokusem autora o vytvoření mainstreamového evropského románu, ale dopadlo to zcela jinak. Román vychází ze životního příběhu ruského malî́re, původem baltského Němce Karla Brjullova, který se podepsal i na životě V. A. Žukovského a T. H. Ševčenka - v dobrém slova smyslu: místo k románu dochází Leskov nakonec k lineární povídce s heterogenní stavbou (Glavy iz neokončennogo romana). To jsem ostatně popsal v knížce Proti proudu (Studie o N. S. Leskovovi, Brno, 1992). Autorka nové edice vycházela z několika textových variant úvodních kapitol, pečlivě je komentovala, vyložila, doplnila jmenným rejstříkem, třicet stran má její výklad tvưrčí geneze díla. V leskovovské textologii měla Alla Šelajevová předchůdkyni, o níž při prezentaci své edice na leskovovském kolokviu v Brně v záŕí 2017 nevěděla: je to práce německé slavistky Ingeborg Gollertové, která analyzovala genezi textu klíčového románu Soborjane (N. S. Leskovs Romanchronik „Die Klerisee“, Berlin, 1969). Obě textologické práce - jedna teoretická i praktická, druhá spíše teoretická a historická - zkoumají dva klíčové momenty na Leskovově tvưrčí cestě: Soborjane se týkají prvního zvratu, Čortovy kukly spíše labutí písně jeho románového úsilí. Nad Leskovovým dílem textologicky svítá. 
Uvedení slova „spřažené“ z titulu recenze má své důvody. Leskov bývá spojován právě s Gorkým, také autodidaktem, jenž Leskova snad právě proto, ale i z jiných př́ičin miloval a postavil ho ve svých přednáškách na Capri - pưvodně outsidera - do centra ruské literatury. Český rusista doc. Jaroslav Burian umírá roku 1980 jako lektor českého jazyka na pařížské Sorbonně. Jeho habilitace o Gorkého románovém díle napsaná původně česky (ruská byla jeho kandidátská disertace o románu Život Klima Samgina obhájená na Lomonosovově univerzitě v Moskvě) vychází nyní rusky péčí univerzity v Nižním Novgorodě s úvodní statí ruského bohemisty Stanislava Rylova, znalkyně díla Maxima Gorkého Mariany Urtmincevové a autora této recenze. J. Burian anticipoval nové př́stupy ke Gorkému, ukázal na jeho vazby - byt rozporné - na ruskou modernu (stříbrný věk), na díla, která spojují Gorkého s Leskovem a tradicí ruského románu (okurovský cyklus), a docenil jeho olbřímí pokus o románovou fresku jako ideovou konkurenci románu Dostojevského Bratři Karamazovovi (Život Klima Samgina). Jeho práce se opírá o novodobé teorie románu, západní i tehdejší sovětské, vychází však také z české komparatistické školy (byl žákem F. Wollmana) a projevuje známé zření k morfologii literárního artefaktu. Pro Rusy může být jeho habilitace v jistém smyslu objevná, nebot ukazuje, že dílo M. Gorkého nemusí být nyní mrtvé, že životem v čase nabývá nových významů, jak to kdysi dosvědčila i dávná česká diskuse na stránkách časopisu Tvorba (1986).

\section{prof. PhDr. Ivo Pospíšil, DrSc.}

Ústav slavistiky

Filozofická fakulta, Masarykova univerzita Arna Nováka 1, 60200 Brno, Česká republika ivo.pospisil@phil.muni.cz 